\title{
Epidemiological Trend of Cutaneous Leishmaniasis in an Endemic Focus Disease During 2009-2016, Central Iran
}

\author{
Kutanöz Leishmaniasis'in 2009 ve 2016 Yillarn Arasinda Orta Iran'da \\ Endemik Bir Bölgedeki Epidemiyolojik Trendi
}

\author{
(1) Doroodgar Moein ${ }^{1}$, (1) Doroodgar Masoud², (1) Nematian Mahmood ${ }^{3}$, (1) Doroodgar Abbas ${ }^{4}$ \\ ${ }^{1}$ Shahid Beheshti University of Medical Sciences, Faculty of Medicine, Tehran, Iran \\ ${ }^{2}$ Aja University of Medical Science, Faculty of Medicine, Tehran, Iran \\ ${ }^{3}$ Kashan University of Medical Sciences, Vice Chancellor of Health, Group of Communicable Diseases, Kashan, Iran \\ ${ }^{4}$ Kashan University of Medical Sciences Faculty of Medicine, Department of Medical Parasitology, Kashan, Iran
}

Cite this article as: Moein D, Masoud D, Mahmood N, Abbas D. Epidemiological Trend of Cutaneous Leishmaniasis in an

Endemic Focus Disease During 2009-2016, Central Iran. Turkiye Parazitol Derg 2019;43(2):55-9.

\begin{abstract}
Objective: Cutaneous leishmaniasis (CL) is one of the common parasitic diseases in tropical and subtropical areas and is one of the important health problems in Iran. In order to investigate epidemiological aspects of CL disease in city of Aran va Bidgol in Isfahan province, this study was carried out in this central region of Iran.

Methods: This cross-sectional study was conducted in over a period of eight years between 2009-2016. Direct smears were prepared from all patients and were examined by a light microscopy. The basic demographic and clinical data of patients with CL disease referred to health care centers were collected and then were analyzed by using the SPSS software.

Results: Overall, 926 patients, including 542 (58.5\%) males and 384 (41.5\%) females with confirmed CL were identified. The CL disease was more common among males (58.5\%). The highest and lowest incidence of the CL disease were estimated as 238.5 and 44.2 per 100000 people in 2009 and 2016, respectively. The highest incidence of the CL disease (26.3\%) was observed in the age group of 0-9 years. Most of the cases (54\%) were seen in autumn. More lesions (44.7\%) were seen on the hands. Of the patients, $65.4 \%$ were treated by systemic glucantime regimen.

Conclusion: According to the results of this investigation, although there is a trend of decrease in the incidence of the CL disease in this 8-year period, incidence of the CL disease is still high. This is an alarming condition and careful planning for control and prevention of the disease is highly recommended.
\end{abstract}

Keywords: Epidemiology, Cutaneous leishmaniasis, Iran

ÖZ

Amaç: Kutanöz leishmaniasis (KL), tropik ve subtropik bölgelerde görülen sık parazitik enfeksiyonlardan biridir ve İran'daki önemli sağlık sorunlarındandır. İsfahan Bölgesi'ndeki Aran va Bidgol şehrinde KL'yi epidemiyolojik açıdan araştırmak için bu çalı̧̧mayı Orta İran'da yaptık.

Yöntemler: Bu kesitsel çalışma 2009 ve 2016 yılları arasında 8 yıllık dönemde yapıldı. Bütün hastalardan smear alındı ve ışık mikroskobu ile incelendi. Sağlık merkezlerine yönlendirilen KL tanılı hastaların temel demografik ve klinik bilgileri toplandı ve SPSS programı ile analiz edildi.

Bulgular: Dokuz yüz yirmi altı KL tanısı konmuş hastanın 542'si (\%58,5) erkek, 384'ü $(\% 41,5)$ kadındı. KL erkeklerde daha fazlaydı (\%58,5). En yüksek ve en düşük KL insidansı 100000'de 238,5 ve 44,2 ile sırasıyla 2009 ve 2016 'da saptanmıştır. En yüksek insidans \%26,3 ile 0-9 yaş grubu hastalarda saptandı. Sonbahar en sık hasta görülen mevsimdi (\%54). En çok lezyon ellerde görüldü (\%44,7). Hastaların \%65,4'ü sistemik glucantime rejimi ile tedavi edildi.

Sonuç: Çalışmamızın sonuçlarına göre, 8 senelik dönemde KL insidansı düşme trendinde olsa da halen KL insidansı yüksektir. Bu, telaşlandırıcı bir durumdur; hastalığın kontrolü ve önlenmesi için dikkatli bir planlama yapılması oldukça önemlidir.

Anahtar Kelimeler: Epidemiyoloji, Kutanöz leishmaniasis, İran

Received/Geliş Tarihi: 09.06.2018 Accepted/Kabul Tarihi: 06.03.2019

Address for Correspondence/Yazar Adresi: Doroodgar Abbas MSc, Kashan University of Medical Sciences Faculty of Medicine,

Department of Medical Parasitology, Kashan, Iran

Phone Tel: +98 9133623454 E-mail/E-Posta: adoroudgar@gmail.com ORCID ID: orcid.org/0000-0003-3247-9637

(C) Copyright 2019 Turkish Society for Parasitology - Available online at www.turkiyeparazitolderg.org

(C) Telif hakkı 2019 Türkiye Parazitoloji Derneği - Makale metnine www.turkiyeparazitolderg.org web sayfasından ulașılabilir. 


\section{INTRODUCTION}

Leishmaniasis is a devastating disease that causes serious health problems around the world (1). The genus of Leishmania is responsible for the leishmaniasis, a group of diseases that were seen much in the tropics and subtropics. The genus of Leishmania is an obligate intracellular protozoan parasite which is transmitted by the bite of infected female Phlebotomine sand flies (Family: Pscychodidae) (2-4). Cutaneous leishmaniasis (CL) is one the leishmaniasis and most common form of the disease, is characterized by the appearance of a skin lesion of one or more ulcers. CL was seen in two forms zoonotic cutaneous leishmaniasis (ZCL) and Anthroponotic CL (ACL). ZCL and ACL caused by Leishmania major and Leishmania tropica respectively. CL disease causes skin ulcers on exposed parts of the body $(5,6)$. Annually, it is estimated that leishmaniasis between 6000001000000 new cases occur around the world. Approximately, 95\% of CL cases happen in the Americas, the Mediterranean basin, the Middle East and Central Asia. More than two third of new CL cases happen in Afghanistan, Algeria, Brazil, Colombia, Iran and the Syria in 2015 (4). In Iran, CL transmission occurs in $17 / 31$ provinces in the country and about 20.000 cases of CL are reported in many parts of Iran annually. But the real numbers are probably three to five times higher the reported extent. There are two forms of the CL, ACL (urban or dry CL) and ZCL (rural or wet CL) (4-6). In many provinces, especially in rural areas and in large and medium-sized cities ZCL and ACL are common respectively. Zoonotic $C L$ is endemic in many rural areas. Over $80 \%$ of $C L$ cases in Iran are ZCL type (3,6-10). The prevalence of CL infection has been reported in different provinces at a variable rate of $1.8 \%$ to $37.9 \%$ (9). Aran va Bidgol is one the populous county in the Isfahan province and is one of the most important foci of ZCL. Results of a study conducted in the Aran va Bidgol region have shown that Leishmania major parasite is the causative agent of the CL disease among patients and Rhombomys opimus and Phlebotomus papatasi are the main reservoir host and vector in the dissemination of the parasite respectively (11). In order to provide a proper plan for the prevention and control of the disease in this region, it is important to know the epidemiological aspects of the CL disease. Therefore, the epidemiological aspects of CL were investigated in the city of Aran va Bidgol between 2009-2016.

\section{METHODS}

This cross-sectional study was conducted in over a period of eight years between 2009-2016.

\section{Study Area}

Aran va Bidgol with an area of $6051 \mathrm{~km}^{2}$ lies $235 \mathrm{~km}$ by road southwest of the capital Tehran and $210 \mathrm{~km}$ from the Isfahan province is in central Iran. This city is located on the southwest border of the central desert of Iran with a typical climate of hot and dry in summer, cold and dry in winter and very little rainfall (100-150 mm) during the year. Its average elevation is 912 meters above sea level and its coordinates are $34^{\circ} 03^{\prime} 28^{\prime \prime} \mathrm{N} 51^{\circ} 29^{\prime} 03^{\prime \prime} \mathrm{E}$ (Figure 1).

\section{Data Collection}

To examine the epidemiological aspects of the CL disease in the Aran va Bidgol district during 2009-2016, this study was conducted and data all of patients with CL disease that were reported from the health care centers were collected. At first, CL infection was clinically diagnosed by a physician and then confirmed by observation of Leishmania parasites by direct smear microscopy from lesions. For all patients, the smear was obtained (from the edges of the lesion) and prepared after fixed with pure methanol and staining with Giemsa. The information obtained was recorded in a checklist containing demographic information such as sex, age, occupation, location of residence, nationality of patients, history of travel in the paste to endemic areas of the disease, season, place or number of acute lesion(s), date of occurrence of lesion(s), results of clinical examination and laboratory tests, the type of treatment regimen.

\section{Statistical Analysis}

The chi-squared tests were used to analyze collected data in SPSS for Windows 16.0 .

\section{RESULTS}

Overall, 926 confirmed CL cases were reported in the city of Aran va Bidgol during 2009 to 2016 period. Five hundred forty-two cases were male (58.5\%) and three hundred eighty-four cases (41.5\%) were female. The disease was common in men and women and statistic test showed that there was no significant association between the sex and disease ( $\mathrm{p}=0.982$ ).

Most of the lesions were observed in $0-9$ years age group (26.3\%), while the lowest rate was found in 50-59 years age group (6.7\%). $42.8 \%$ of patients with CL were in the age group of $0-19$ years (Table 1). There was no significant relationship between the job and disease $(p>0.05)$. The age of the patients varied from one month to 90 years and up to 40 lesions was observed in an Iranian 25-year-old worker. In terms of occupation, $23.3 \%$ were homemaker, $22.5 \%$ young children, $15.6 \%$ workers, $15.2 \%$ students, and so on (Table 1). No significant correlation was found between age groups and active disease ( $\mathrm{p}=0.973)$.

Due to the location of the lesion in the body, hands were the most affected (44.7\%) and then legs (23.3\%), face (19.2\%) and so on. $79.3 \%$ of patients with CL lived in urban and $26.1 \%$ in rural centers ( $p>0.05$ ). $48.5 \%$ of patients had a single lesion, $24.5 \%$ had two lesions and the rest had multiple lesions. $42.3 \%$ of cases had a history of traveling to endemic areas CL. $86 \%$ of patients with CL were Iranian and the rest belonged to other nations. Cases of CL

\begin{tabular}{|c|c|c|}
\hline Characters & Categories & No (\%) \\
\hline \multirow{2}{*}{ Gender } & Male & $542(58.5)$ \\
\hline & Female & $384(41.5)$ \\
\hline \multirow{7}{*}{ Age group } & $0-9$ & $244(26.3)$ \\
\hline & 10-19 & 153 (16.5) \\
\hline & $20-29$ & $160(17.3)$ \\
\hline & $30-39$ & $128(13.8)$ \\
\hline & $40-49$ & $91(9.8)$ \\
\hline & $50-59$ & $62(6.7)$ \\
\hline & $\geq 60$ & $88(9.6)$ \\
\hline
\end{tabular}




\section{Table 1 contiuned}

\begin{tabular}{|c|c|c|}
\hline \multirow{7}{*}{ Job } & Homemaker & 216 (23.3) \\
\hline & Student & $144(15.6)$ \\
\hline & Worker & $208(22.5)$ \\
\hline & Child & $141(15.2)$ \\
\hline & Farmer & $33(3.5)$ \\
\hline & Driver & $10(1.1)$ \\
\hline & Other & $174(18.8)$ \\
\hline \multirow{5}{*}{ Place of lesion } & Hands & $414(44.7)$ \\
\hline & Feet & $216(23.3)$ \\
\hline & Face & $178(19.2)$ \\
\hline & Trunk & $29(3.1)$ \\
\hline & Other places & 89 (9.7) \\
\hline \multirow{2}{*}{ Residence } & Urban & $684(73.9)$ \\
\hline & Rural & $242(26.1)$ \\
\hline \multirow{2}{*}{ Travel history } & Yes & $392(42.3)$ \\
\hline & No & $534(57.7)$ \\
\hline \multirow{2}{*}{ Nationality } & Iranian & 796 (86) \\
\hline & Non-Iranian & $130(14)$ \\
\hline \multirow{4}{*}{ Season } & Spring & $22(2.4)$ \\
\hline & Summer & 301 (32.5) \\
\hline & Autumn & $501(54.1)$ \\
\hline & Winter & $102(11)$ \\
\hline \multirow{8}{*}{ Year } & 2009 & $220(23.8)$ \\
\hline & 2010 & $95(10.3)$ \\
\hline & 2011 & $105(11.3)$ \\
\hline & 2012 & $242(26.1)$ \\
\hline & 2013 & $64(6.9)$ \\
\hline & 2014 & $106(11.4)$ \\
\hline & 2015 & $46(5)$ \\
\hline & 2016 & $48(5.2)$ \\
\hline \multirow{6}{*}{ Treatment } & Systemic glucantime & $605(65.4)$ \\
\hline & Topical glucantime & $103(11.2)$ \\
\hline & $\begin{array}{l}\text { Topical glucantime \& } \\
\text { cryotherapy }\end{array}$ & $89(9.6)$ \\
\hline & Cryotherapy & $79(8.5)$ \\
\hline & Not indicated & $7(0.7)$ \\
\hline & Other & $43(4.6)$ \\
\hline
\end{tabular}

during autumn were higher compared with those during summer. The number of cases was higher in the months of October, November and December (20\%, $24 \%$ and $13 \%$, respectively). The lowest frequency of CL cases was seen in spring (2.4\%) (Table 1). The most cases were observed in 2012 (26.2\%) and the lowest (5\%) was in 2015. The highest annual incidence of CL was

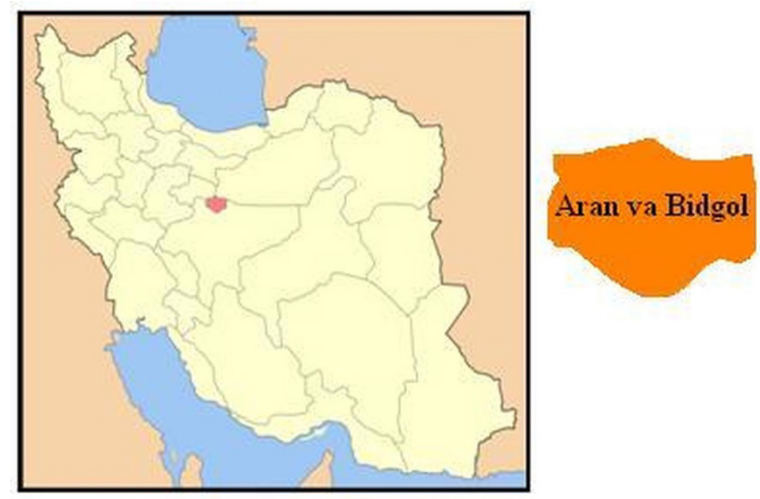

Figure 1. Geographical location of Aran va Bidgol County in Map of Iran, region of study

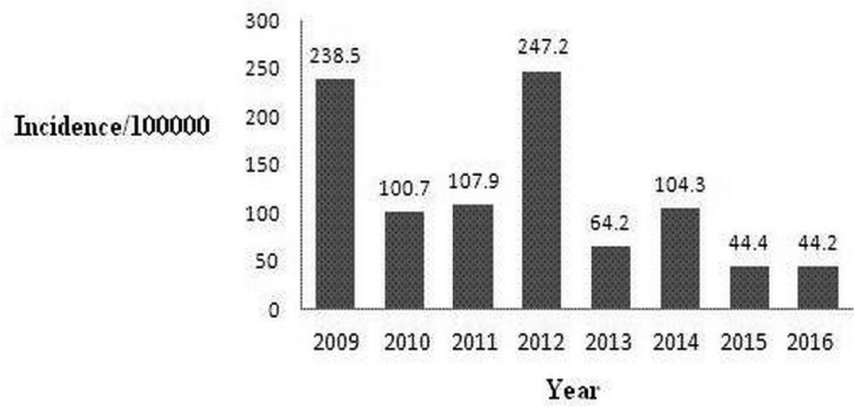

Figure 2. Annual incidence of cutaneous leishmaniasis per 100.000 Populations in city of Aran va Bidgol between 20092016

estimated to be 247.2 per 100.000 in 2012 and the least 44.2 per 100,000 in 2016 (Figure 1). The most common treatment regimen was systemic Glucantim (65.4\%) (Table 1). Chi-square test showed that there was a significant difference between the treatment regimen and the disease $(\mathrm{p}=0.736)$.

\section{DISCUSSION}

The incidence of the CL disease is increasing throughout the world and in various parts of the Islamic Republic of Iran. We conducted the present study to investigate epidemiological aspects and the incidence of CL in the city of Aran va Bidgol, Isfahan province. In this study, 926 confirmed patient with CL were observed in an 8-year period. According to the misdiagnosed and self-healing cases and available scientific references (3), it is estimated that the real cases to be 3 to 5 times higher, nearly 5000 local populations were infected with $C L$ in this city. The results of the present study showed that both sexes and all age groups were at risk for $\mathrm{CL}$ disease. Similar findings have been reported in various studies conducted in Iran $(6,10)$, in Libya, South-West of Kerman, Morocco, Qom province, Kerman province (12-16). In our study, most patients were male (58.5\%). Similar results have been reported in some other studies, including Golestan province, Yazd province, and Bushehr province $(15,17,18)$. The higher incidence of CL disease in men compared to women can be justified by the behavior of men as wearing less clothing, more presence outside the home to carry out normal social and/ or occupational activities or working in open environments after sunset and throughout the night, when the infected sand 
flies bite and bloodsucking. In this study, considering the job of patients with CL, the highest prevalence of CL was observed in housewives. Other studies, including studies conducted in Iran, Fars province, Bushehr province and Qom province reported similar results. $(14,18,19)$ But our result is inconsistent with the findings of a study conducted in Isfahan (20). In the present study, the higher prevalence of CL in housewives could be due to economic and carpet weaving activities in low light rooms in the days. In these places, sand flies can continue to bloodsucking and infected human. Our study also indicated that the majority of the CL patients belonged to the 0-9 year age group (26.3\%). Our finding is consistent with the results of the studies in Omidieh and Ahvaz $(21,22)$ and is inconsistent with the results of some internal and external investigations conducted in Fars province, Kermanshah, Isfahan, Khatam County, Morocco and Libya $(12,19,20,23,24)$. The highest frequency of CL was showed in the age group of 0-9 years. More infections in this age group can be justified by these reasons when the level of endemicity of CL disease is high; the disease occurs in children under one year or children under school age and on the other hand, may be due to the low immune system susceptibility of children to fight CL parasites. According to the finding of this study, about $65 \%$ of patients with CL were observed in the second half of the year (autumn and winter seasons), which indicates the dominant rural type of the $\mathrm{CL}$ disease in this region. The results showed that nearly $51.5 \%$ of patients had more than one lesion on the body. Several studies that described the epidemiological aspects of the CL disease have reported that most patients had multiple wounds $(14,18,20,22,25)$. Our results are consistent with the findings of these studies. The results of this study showed that $65.4 \%$ of patients with $C L$ were treated with systemic glucantime. According to multiple lesions in different parts of the patient's body and with regards to the use of the glucantime drug as the first line in CL treatment in Iran, this regimen has been used more than others.

As can be seen in Figure 2, the highest incidence of CL was estimated at 2012 and the lowest at 2016. Changes in managerial and environmental factors may cause fluctuations in the incidence rate of the $C L$ disease in different years. Although in recent years, there has been a downward trend in the CL disease incidence in the city of Aran va Bidgol. However, the CL incidence in this city is more than the average rate of CL incidence in Iran (27 per 100,000 in 2011) (8) and CL is still a public health problem in the city of Aran va Bidgol. Conflicting results have been reported in many studies based on an increased of the CL incidence rate in the investigated areas $(19,25)$. The declining trend may be due to some factors, including, control of the parasite vectors and reservoir hosts, early diagnosis and treatment of the disease and increasing people's awareness on the use of personal protection methods. The incidence time graph of the CL disease in the 8 years period study, showed an increase and decrease in CL incidence during this study. Other investigations have reported similar findings $(15,24,26-30)$.

\section{CONCLUSION}

This study showed that the CL disease is endemic in the city of Aran va Bidgol and at the present time, this disease is an important public health problem in this region.
Considering the high incidence rate of the disease in this endemic region, to prevent an outbreak of the disease, it is necessary to control strategies is carried out as in the past. It is recommended, before beginning sand flies activities, a rodent control program run at a radius of 500 meters around the at-risk villages. Also health education and raising of awareness of the area residents about observing health principles, the cycle of disease transmission and personal protection in preventing the disease are very important. Also, it is suggested, periodic and regular visits are performed by health experts from the region.

\section{* Ethics}

Ethics approval consent: This study was conducted on the basic demographic and clinical data of the patients with CL disease were collected from health care centers.

Informed Consent: Patient approval was received.

\section{*Authorship Contributions}

Concept: D.M., D.A., Design: D.A., D.M., Data Collection or Processing: D.A., D.Ma., N.M., D.A., Analysis or Interpretation: D.M., D.Ma, Literature Search: D.M., D.A., D.Ma, Writing: D.A.

Conflict of Interest: The authors declare that there is no conflict of interest.

Financial Disclosure: The authors have no financial disclosures to report.

Acknowledgments: The authors would like to thank all those who have collaborated in this research, especially Mr. Saeed Mahboobi in Kashan University of Medical Sciences, Vice Chancellor of Health, Group of communicable diseases, Kashan, Iran.

\section{REFERENCES}

1. Read A, Hurwitz I, Durvasula R. Leishmaniasis: An Update on a Neglected Tropical Disease. In: Rao V., Durvasula R. (editors) Dynamic Models of Infectious Diseases; 2013. Springer, New York, NY.

2. Meireles CB, Maia LC, Soares GC, Teodoro IPP, Gadelha MDSV, da Silva CGL, et al. Atypical presentations of cutaneous leishmaniasis: A systematic review. Acta Trop 2017;172:240-54.

3. Bates PA. Transmission of Leishmania metacyclic promastigotes by phlebotomine sand flies. Int J Parasitol 2007;37:1097-106.

4. World Health Organization. Leishmaniasis. Available at http://www.who. int/mediacentre/factsheets/fs375/en/. Fact sheet, Updated March 2018.

5. Doroodgar M, Doroodgar M, Doroodgar A. Unusual Presentation of Cutaneous Leishmaniasis: Ocular Leishmaniasis. Case Rep Infect Dis 2017;2017:3198547.

6. Yaghoobi-Ershadi MR. Phlebotomine Sand Flies (Diptera: Psychodidae) in Iran and their Role on Leishmania Transmission. J Arthropod Borne Dis 2012;6:1-17.

7. Yaghoobi-Ershadi MR. Control of Phlebotomine Sand Flies in Iran: A Review Article. J Arthropod Borne Dis 2016;10:429-44.

8. Shirzadi M, Mohebali M, Yaghoobi-Ershadi MR, Firooz AR, Sharifi E, Fekree AR, et al. Guidelines of care for cutaneous leishmaniasis in Iran. Iran: Advertising Center Negahe Armani Press;2012.p.114.

9. Yaghoobi-Ershadi MR, Hanafi-Bojd AA, Javadian E, Jafari R, ZahraeiRamazani AR, Mohebali M. A new focus of cutaneous leishmaniasis caused by Leishmania tropica. Saudi Med J 2002;23:291-4.

10. Khazaei S, Mohammadian Hafshejani A, Saatchi M, Salehiniya H, Nematollahi S. Epidemiological Aspects of Cutaneous Leishmaniasis in Iran. Arch Clin Infect Dis 2015;10:e28511. 
11. Doroodgar Abbas, Sadr F, Razavi MR, Doroodgar Moein, Asmar M, Doroodgar Masoud. A new focus of zoonotic cutaneous leishmaniasis in Isfahan Province, Central Iran. Asian Pac J Trop Dis 2015;5:54-8.

12. Abdellatif MZM, El-Mabrouk K, Ewis AA. An epidemiological study of cutaneous leishmaniasis in Al-jabal Al-gharbi, Libya. Korean J Parasitol 2013;51:75-84.

13. Khosravi A. Sharifi I, Dortaj E, Aghaei Afshar A, Mostafavi M. The present status of cutaneous leishmaniasis in a recently emerged focus in Southwest of kerman province, iran. Iran J Public Health 2013;42:182-7.

14. Rassi Y, Saghafipour A, Abai MR, Oshaghi MA, Mohebali M, Mostafavi R. Determination of Leishmania Parasite Species of Cutaneous Leishmaniasis Using PCR Method in Central County, Qom Province. Zahedan J Res Med Sci 2013;15:13-6.

15. Barati H, Lotfi MH, Mozaffari GA, Barati M, Dehghan HR, Taj Firouze AA. Epidemiological Aspects of Cutaneous Leishmaniasis in Yazd Province within 2004-2013. Journal of Community Health Research 2016;5:131-9.

16. Sharifi I, Aflatoonian MR, Fekri AR, Hakimi Parizi M, Aghaei Afshar A, Khosravi A, et al. A comprehensive review of cutaneous leishmaniasis in kerman province, southeastern iran-narrative review article. Iran J Public Health 2015;44:299-307.

17. Mollalo A, Alimohammadi A, Shirzadi MR, Malek MR. Geographic information system-based analysis of the spatial and spatio-temporal distribution of zoonotic cutaneous leishmaniasis in Golestan Province, north-east of Iran. Zoonoses Public Health 2015;62:18-28.

18. Hamzavi Y, Foruzani AR, Mohebali M. Frequency of cutaneous leishmaniasis in Bushehr province, 1983-1999. Behbood J 2001;5:24-6.

19. Fattahi Bafghi A, Eftekhari M, Ahmadi S, Moghateli M. Epidemiological Pattern of Cutaneous Leishmaniasis in the Province of Fars, Iran (20102014). J Community Health Res 2016;5:240-8.

20. Karami M, Doudi M, Setorki M. Assessing epidemiology of cutaneous leishmaniasis in Isfahan, Iran. J J Vector Borne Dis 2013;50:30-7.
21. Behbahani AA, Ahmadi S, Latifi SM, Sadeghi M. Study of the frequency of Cutaneous Leishmaniasis in Omidieh district, Khouzestan province, south west of Iran (2008 2010). Jundishapur J Health Sci 2012;4:37-46

22. Vazirianzadeh B, Kamalvandi M, Shamsi J, Viesbehbahani R, Amraee $\mathrm{K}$, Shams Sollary S. Epidemiology of cutaneous leishmaniasis in west of Ahvaz district . Khuzestan province, soutewestern of Iran. J. Exp. Zool. India 2014;17:219-22.

23. Yaghoobi-Ershadi MR, Marvi-Moghadam N, Jafari R, Akhavan AA, Solimani H, Zahrai-Ramazani AR, et al. Some Epidemiological Aspects of Cutaneous Leishmaniasis in a New Focus, Central Iran. Dermatol Res Pract 2015;2015:286408.

24. Kahime K, Boussaa S, Laamrani-ElIdrissi A, Nhammi H, Boumezzough A. Epidemiological study on acute cutaneous leishmaniasis in Morocco. Journal of Acute Disease 2016;5:41-5.

25. Doroodgar A, Sayyah M, Doroodgar M, Mahbobi S, Nemetian M, Rafizadeh S, et al. Progressive increasing of cutaneous leishmaniasis in Kashan district, central of Iran. Asian Pac J Trop Dis 2012;2:260-3.

26. Norouzinezhad F, Ghaffari F, Norouzinejad A, Kaveh F, Gouya MM. Cutaneous leishmaniasis in Iran: Results from an epidemiological study in urban and rural provinces. Asian Pac J Trop Biomed 2016;6:614-9.

27. Israa SM, Sinan Ghazi M, Entsar JS, Muthana Ibrahim AK, Adnan Nawar K. An Epidemiology Study of Some Protozoan Parasitic Diseases in Iraq from 2011 Till 2015. Al-Nahrain Uni J 2017;20:115-20.

28. Zare M, Rezaianzadeh A, Tabatabaee1 H, Aliakbarpoor M, Faramarzi H, Ebrahimi M. Spatiotemporal clustering of cutaneous leishmaniasis in Fars province, Iran. Asian Pac J Trop Biomed 2017;7:862-9.

29. Nazari M, Nazari S, Hanafi-Bojd AA, Najafi A, Nazari S. Situation analysis of cutaneous leishmaniasis in an endemic area, south of Iran. Asian Pac J Trop Med 2017;10:92-7.

30. Moein D, Masoud D, Saeed M, Abbas D. Epidemiological Aspects of Cutaneous Leishmaniasis during 2009-2016 in Kashan City, Central Iran. Korean J Parasitol 2018;56:2124. 